\title{
Weonomics
}

Central European Review of Economics \& Finance

Vol. 25, No. 3(2018), pp. 21-35

DOI: $10.24136 /$ ceref.2018.013

Received: 6 February 2018. Accepted: 2 May 2018

Robin GOWERS ${ }^{1}$, Anna PAJĄK ${ }^{2}$, Edgar KLUSA ${ }^{3}$

\section{CULTURAL DETERMINANTS AND PERSPECTIVES OF INTERNATIONAL EXPANSION OF ENTERPRISES FROM ECONOMIES IN TRANSITION (CASE OF POLAND)}

Within this article the authors identify and analyze the key cultural success factors for companies when developing strategies to move out of their home market. Such strategies can often involve significant cost and risk. However, many companies fail due to overlooking the cultural aspects of entering new arenas. The approach used in the article analyzes culture in the wider perspective, from the individual to the national dimensions, looking for the important roots in the historical and institutional backgrounds that need to be considered when developing strategies. A focus on Polish companies is then developed. Poland, representing a post-transition economy, is an interesting case study in the context of cultural and social factors in internationalization, especially in the light of important ongoing transitions on the global scene. The aim of the authors is to highlight the most characteristic cultural determinants that may be seen as the most adequate when analyzing cultural issues in the context of internationalization processes of developing or in transition economies.

Keywords: globalization, cultural diversity, transition economies, entry strategies.

JEL Classification Codes: P31, F61.

\section{Introduction}

According to Dobbs et al. (2015) 2000 listed companies from developed countries spent nearly $\$ 4.5$ trillion on increasing the scale of their operations around the world,

\footnotetext{
${ }^{1} \mathrm{PhD}$, Senior Lecturer, Writtle University College.

${ }^{2}$ Institute for Sustainable Technologies - National Research Institute.

${ }^{3}$ MA, PhD student, University of Technology and Humanities in Radom.
} 
and most of those investments were dedicated to emerging markets, which have become an increasingly important source of profits. In 1980 the emerging market area accounted for $21 \%$ of global food and drinks sales, $14 \%$ of electronic equipment and $11 \%$ of cars. In 2013 these shares had increased to 53,56 and $42 \%$ respectively. In reaction to this trend, many Western companies transformed from local operating enterprises into global organizations. Dobbs et al. (2015) state that in 2010 almost half of the revenues of firms from the S\&P 500 index was coming from outside of United States.

The increasingly global connected world requires relevant studies that help the management of global organizations maintain positive international relations and establish long-term profitable cooperation for all stakeholders involved. In establishing successful entry and marketing strategies cultural aspects therefore play an important part. As Hofstede et al. (2010) pointed out, „all peoples have considered their country as the center of the world", and this ethnocentrism has many implications in business activities today. It is common that leaders of global organizations achieve poor performance because of the inability to adapt their management style and practices to a multicultural environment (Neeley et al. 2015). The assumptions made in one country very often are not applicable in other regions (Khanna, 2015). Globalization allows cultures to traverse national borders, causing many transitions or new phenomenon like culture diffusion or hybridization (Nakata et al., 2009) and depict a world more complex, conceivably less stable, and further interconnected. Technology development with big platform and digital networks provide new tools for reaching mass markets of customers. But, at the same time, we cannot deny the existence of boundaries and borders. As Tietze (2008) points out, some of them may become permeable or eroded, but others may be firmer and more defined. All the cultural phenomenon force global corporations with billions of dollars in revenues to think like smaller enterprises, thus requiring new hypotheses on the occasion of entering new markets (Khanna, 2015). It is clear that there is no one way to reach consumers and to build sustained relations. Culture is an ambiguous concept, at the same time complex and amorphous (Douglas and Craig, 2009, p. 127). Differences may manifest themselves in an alternative sense of justice, readiness to cooperate, conclusion schemes (either inductive or moral), and levels of trust (Khanna, 2015). At the same time, culture is expressed in different strata: country (and in relations between them), organization, group and, finally, individual, as well as in diverse forms. Therefore, the first two parts of the paper are dedicated the cultural aspects, presented through the prism of the 'culture in business' issues in part 1, and with the specific focus on the Polish culture analysis, based on the chosen theoretical frameworks and models briefly presented in part 2. Part 3 presents the international expansion perspectives and trends of Poland as an economy in transition with the comparison to the other economies of similar characteristics. Main conclusions are presented in part 4. The empirical base, such as the representative research describing characteristics of Polish enterprises' international activities in the timeframe of last 10 years, as well as the reports of inter- 
national organizations monitoring international Trade and Foreign Direct Investments, provide the basis for analyzing the importance of socio-cultural and economic factors in international performance of Polish enterprises.

\section{Culture in Business - Frameworks Overview}

One of the dominant culture paradigms in the area of business studies is that of Geert Hofstede [vide: Hofstede, 1980] that was first presented in Culture's Consequences. International Differences Work-related Values. This paradigm, based on the cognitive construct, rate nations by the constant values and expressions within the societies. Hofstede (2001, p. 9) defined culture as "the collective programming of the mind that distinguished one group or category of people from another". According to Hofstede, culture is collective, learned and acquired and the national identity is the most distinguishing aspect of people's diversity as it reflects people's cultural mind programming, shapes the values, norms, attitudes, perception and behaviors. His model of national culture is based on six dimensions that represents specific characteristics and preferences of different nations: power distance, individualism vs. collectivism, masculinity versus femininity, avoidance of uncertainty, long vs. short term orientation, indulgence versus restraint.

Edward Hall (Hall\&Hall, 1990) analyzes culture through the prism of communication. His concept of culture is embedded on characteristics of human communication styles and preferences and, similar to Hofstede's approach, refers to national (country) distinctions where, „Each cultural world operates according to its own internal dynamic, its own principles, and its own laws - written and unwritten" [vide: Hall 1984].

Richard Gesteland (2005, p. 17-18) emphasized the two Iron Rules in International Business in the context of international sales and marketing: 1) "In International Business, The Seller Adapts to the Buyer”, 2) „In International Business, the Visitor Is Expected to Observe Local Customs". In his approach to cultural differences in international business relations („Cross-Cultural Business Behavior”), the classification of national cultures is built on four patterns (Gesteland, 2005, pp. 18-19): Deal Focus vs. Relationship Focus; Informal (Egalitarian) vs. Formal (Hierarchical); Rigid-time (Monochronic) vs. Fluid-Time (Polychronic); Emotionally Expressive vs. Emotionally Reserved.

Culture thus has a fluid nature and changes over time, therefore, the new approaches enrich the traditional theories deriving their inspiration from the existing frameworks and adding a critical evaluation. For example, Nakata et al. $(2009$, p. 12) offer various definitions and approaches to understanding the meaning of culture in the modern global business environment, e.g.: „the meanings that people attach to the world”, „networks of systematically diverse principles of action and understanding”, „adaptive systems rooted in social context”, „continuously negotiated meanings of belonging”. 
Khanna (2015) underlined the importance of "contextual intelligence”, as the ability to perceive the limitation of knowledge and the necessity to adapt it to the specifics of the environment that people are performing on. This contextual intelligence requires going far beyond analysis of the institutional context to exploring new, diverse areas such as intellectual property, aesthetic preferences, attitude to authority, free markets, as well as religious differences. The range of required adaptive changes may sometimes be so wide that it may be contradictory to essential business model (Khanna, 2015). Nevertheless, as Khanna argues, adaptation to the cultural and institutional context has a greater impact on future success on foreign markets than technology or finance resources. In the opinion of Brannen (2009), "global leaders find themselves stereotype rich and operationally poor where culture meets context" (for more, see: Nakata et al., 2009, pp.81-96).

Thomas and Peterson (2015, pp.11-20) highlight the problem of the limitation of present management studies and lack of universality, since most of theories grew out of United States based approaches. The universal ideas of management manifest themselves in various different ways in different cultural backgrounds, that is why implementation of best practices is not always possible. It is crucial for global organizations and the ones with international and global aspirations to recognize the differences between universal principles and their local manifestations and adapt accordingly. It is therefore important to analyze the internationalization processes from different perspectives, among which cultural aspects should have an important place. Analysis of historical aspects and national culture characteristics can therefore provide interesting foundations for identifying key factors of successes of international expansion.

\section{Characteristics of Poland in Relation to Other National cultures}

It is difficult to clearly characterize Polish culture since some tensions and contradictions appear in many dimensions which have their roots in important changes in the political system that still have their implications in people's behavior. Deep distinctions are seen not only between different generations, as takes place in many nations, but also between metaphorically named "beneficiary" and "victims" of transformation. These two groups represent different ethic codes and behaviors. The „beneficiary” group represent more cosmopolitan and liberal approach, they advocate for international exchange and at the same time are more, focused on deals and goals that long-term relationships and less formal. The "victims" group consist people directed to tradition, more passive and change reluctant (Stępień et al., 2011, pp.178-181). The ground of cultural differentiation and various behavior approaches within society can undoubtedly be found also in historical background, annexations and internal fragmentations through the ages. 


\subsection{Poland in Gesteland's framework}

According to Gesteland's (2005) forty Negotiator Profiles, representing eight groups of countries, Poland is considered as: Relationship-Focused, which characterize cultures with the high concentration on personal relationships, where contacts with close relatives, friends and well know partners are preferred. Trust, connections and the good opinion of others is important while establishing new business partnerships. The deal, in contrast to Deal-Focused cultures, is less important than partner and personal bonds. What needs to be underlined here is deep distinction seen between different generations in Poland, since the younger generation has tendency to deal-focused attitude; Formal, what stands for cultures where social status and hierarchy is important, and power distance is high. Polychronic, suggests a liberal approach to time. It can manifest itself in paying less attention to deadlines and schedules when personal relations are stated in the first place. Whereas, more monochromic patterns of approach can be noticed in the younger generation. Variably Expressive means standing between highly emotional and reserved behaviors and communication style.

\subsection{Poland in Hofstede's Framework}

Poland, at a score of 68 can be recognized as a hierarchical society. It means that inequities between people (e.g. within organizations) are generally accepted, considered as reasonable and even desirable. At the same time, with an individualism score of 60 , Polish culture may be considered as a medium individualist nation, while many collective tendencies can also be found. Collectivism underlines the importance of the group (family, nation, society), where building relationships is more important than achieving goals. This specific "contradiction” expressed in pretty high Individualism and power distance level at the same time is worth underlining. It shows the internal heterogeneity of attitudes while individuals deal with an ingrained tendency to high level of power distance within the society. With the score of 64 on masculinity dimension, Poland represents medium masculine culture with the slight indication toward masculinity. It can suggest the balance between different approaches to gender roles, but as well it can be the sign of dissection and underline differences within the society, what seems to be more true in case of Polish culture. Poland, as a country of very high preference for avoiding uncertainty (score 93) is the nation where control and predictability are important, as well as trust and written and unwritten rules play significant role. Poland's low score of 38 in the time dimension place the country in the position of short-time oriented, where traditions and norms are maintained and people tend to look for past to find general patterns for behavior, while at the same time looking for quick results in the future. Having a low score (29), Polish culture can be described as restraint. It suggest pessimistic attitudes toward people, tendency to control desires and respectability to the social norms. 


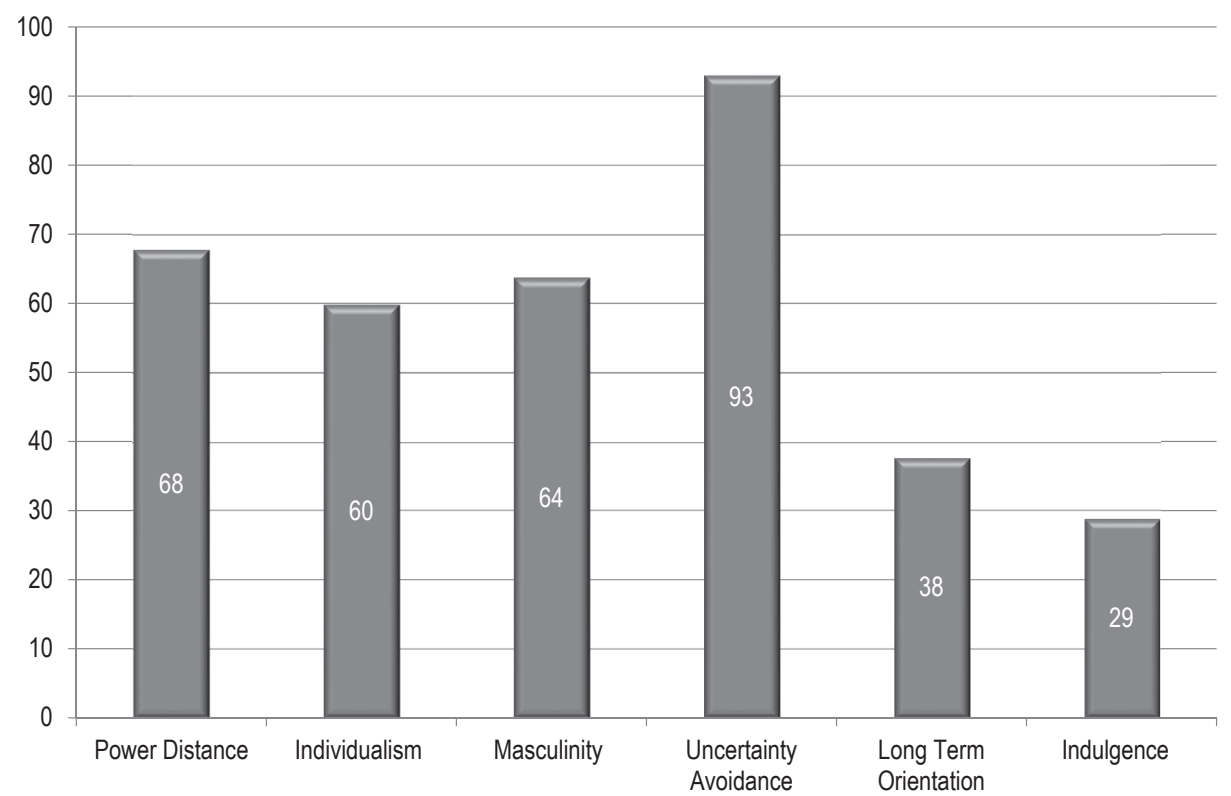

Figure 1. The Polish culture through the lens of Hofstede's 6D model

Source: authors, based on: https://geert-hofstede.com/poland.html

The specific cultural dissection of Polish society has implications to economic activity and business cooperation. It may bring light on the question why Polish enterprises can be successful at entering new markets. For example, as the representatives of a medium individual culture Polish enterprises may be more predisposed to communicate and cooperate with both, highly individual (e.g. United States) and collective (e.g. China) cultures. At the same time, living in highly differential society, representatives of Polish culture are facing the problem of dealing with diversity and different attitudes and beliefs within own society. Presented features and determinants may be seen as the important factors for the analysis of the international expansion of Polish companies, its potential, trends, characteristics and factors of success.

\section{Poland: International Expansion Perspectives}

Poland as a post-transition economy is an interesting subject of study in the context of cultural and social factors in internationalization and the global expansion of companies. Political transformation and hence, economic transition processes in the early nineties, liberated the market and opened new perspectives and opportunities for Polish enterprises. Accession to the European Union in May 2004 had a huge impact on the foreign activity of Polish enterprises. As a result since 2005 there has been big growth in Polish FDI. In 2014 the outward FDI of Polish investors abroad was equal €22.3bn, 
an increase of 73 times in comparison to 2003. Before accession the annual cumulative Polish FDI did not exceed $€ 412 \mathrm{~m}$. It should be underlined that growth of Polish FDI is the reflection of both, deep economic transformations, and the increasing maturity of Polish enterprises.

The last decade brought a dynamic development of the number and amount of Polish companies' investments abroad as well as their export activities. The changes in Polish total export turnover are presented in Figure 2.

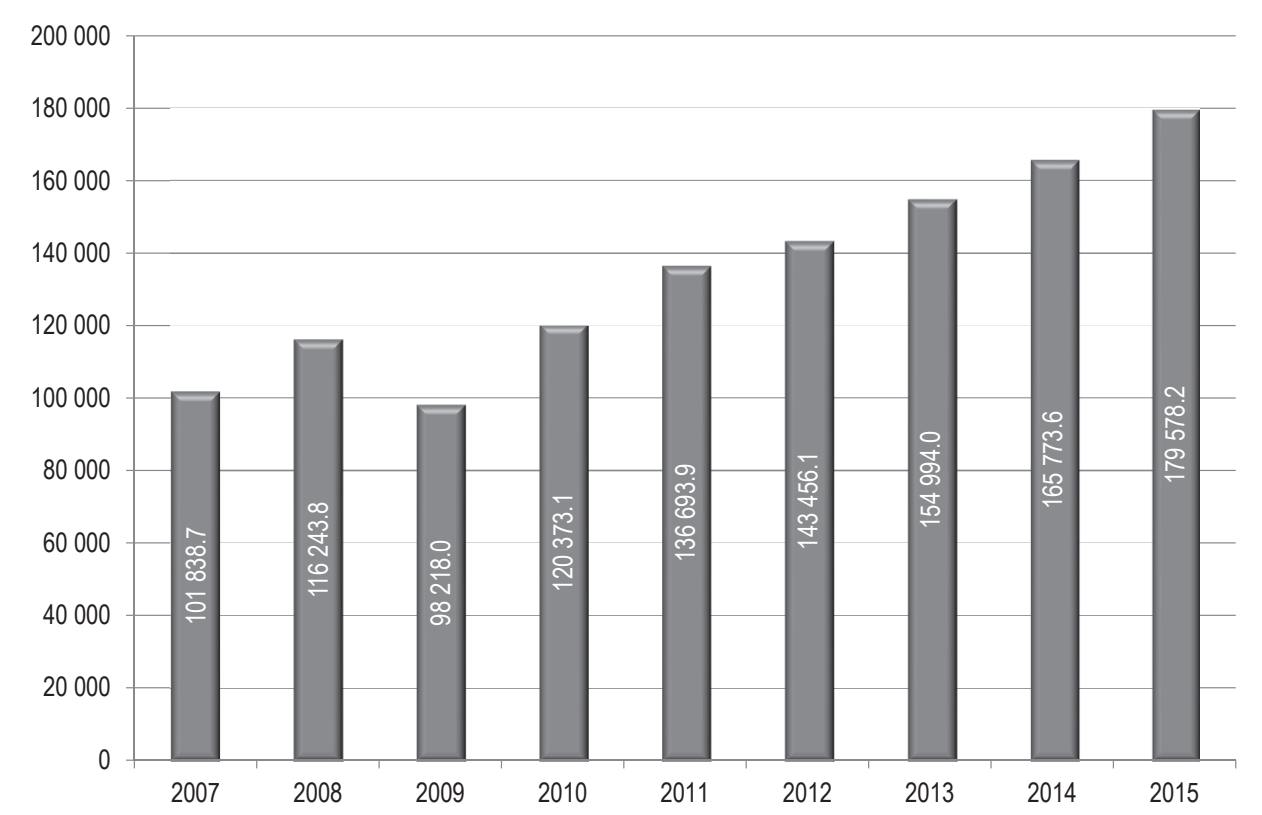

Figure 2. Polish total export turnover for 2007-2015 in $€ \mathrm{mln}$

Source: authors, based on: 'Year Book of Foreign Trade Statistics of Poland' (Warsaw 2012, Warsaw 2016), Central Statistical Office.

The most popular strategy of entering foreign markets by Polish enterprises, was the direct export of goods and services. But as the dynamic growth of foreign direct investment can be seen, Polish companies were also setting up operations overseas, taking over foreign firms or establishing joint ventures with them. This is a high risk, potential high return strategy. Figure 3 presents the numbers of polish entities and their foreign units in the years 2008-2014.

With regard to the location of their foreign entities, the most popular directions of investments by Polish companies were countries bordering with Poland: Germany, Ukraine, Czech Republic. As showed in Table 1, also the level of investments outside the EU has been increasing. 


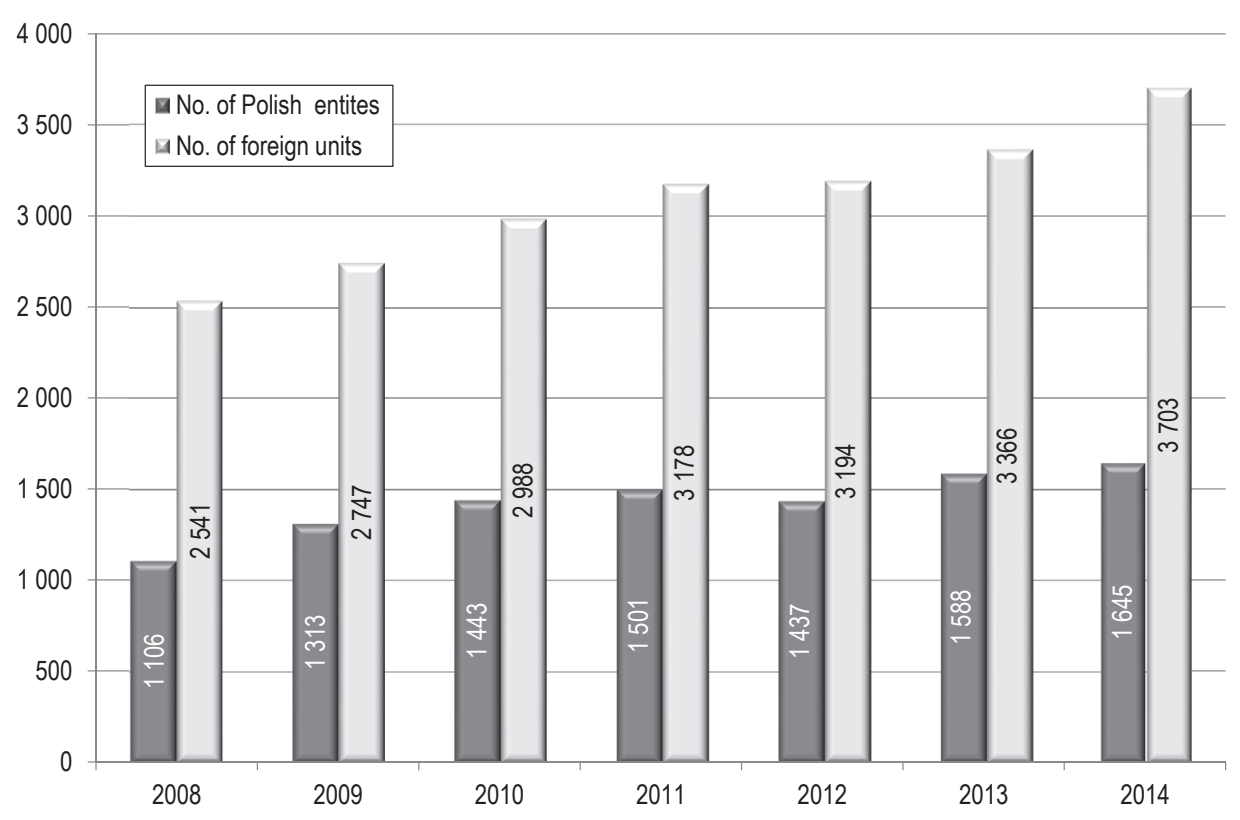

Figure 3. Number of Polish entities and their units abroad for 2008-2014

Source: authors, based on: 'Activity of enterprises having foreign entities in the years 2008 - 2014', Polish Central Statistical Office, Warsaw 2016

Table 1. Number of foreign units by continents for 2008-2014

\begin{tabular}{|c|c|c|c|c|c|c|c|}
\hline \multicolumn{7}{|c|}{ Number of foreign units by continents } \\
\hline & Europa & Asia & Africa & $\begin{array}{c}\text { South } \\
\text { America }\end{array}$ & $\begin{array}{c}\text { North } \\
\text { America }\end{array}$ & $\begin{array}{c}\text { Australia } \\
\text { \& Ocenia }\end{array}$ & Total \\
\hline 2008 & 2206 & 127 & 38 & 11 & 138 & 21 & 2541 \\
\hline 2009 & 2411 & 122 & 35 & 9 & 150 & 20 & 2747 \\
\hline 2010 & 2610 & 153 & 36 & 13 & 164 & 12 & 2988 \\
\hline 2011 & 2794 & 160 & 32 & 16 & 164 & 12 & 3178 \\
\hline 2012 & 2762 & 179 & 44 & 22 & 173 & 14 & 3194 \\
\hline 2013 & 2922 & 176 & 55 & 25 & 178 & 10 & 3366 \\
\hline 2014 & 3109 & 258 & 69 & 29 & 217 & 21 & 3703 \\
\hline
\end{tabular}

Source: author, based on: 'Activity of enterprises having foreign entities in the years 2008 - 2014', Warsaw 2016 Polish Central Statistical Office (2016c)

For many Polish enterprises, capital investments abroad are still the matter of finding new markets and lower labor costs. Nevertheless, more firms' motives are connected with the ability to get access to alternative sources of raw materials, or other strategic resources, as well as buying shares or acquisitions of foreign entities (greenfield investments) (Ministry of Development, 2016). Furthermore, analysis of Polish companies 
listed on the Warsaw Exchange Stock shows that the internationalization processes of Polish companies combine experiences of both emerged and emerging markets, having many characteristics common for both of types of economies (Radło\&Ciesielska, 2016). Polish enterprises also tend to increase their investments on the mature markets of the EU, what shall be indicated as the "reverse" FDI. This is opposite to the classical framework of FDI, from the less developed to more wealthy countries (Ministry of Development, 2016), In the last few years more investments have also been located outside Europe, e. g. in US, Canada or India.

It is worth noting that the share of Polish direct investment in the global economy is still very low and in 2014 covered only $0.38 \%$ of the total amount. Compared to the higher developed European economies, Polish FDI still equals to around 3\% of the investment of the countries like United Kingdom, France or Germany. From the country perspective it is, nevertheless a vital indicator of important changes in growth and development. In 2004 the share of FDI abroad in Poland's GDP was 2.08\% it grew to $10.64 \%$ in 2013 (Ciesielska et al., 2016). A point of reference for Polish FDI can be the other countries that joined the EU in 2004 or later, and most of which are characterized as a transition economies ${ }^{4}$. Similar to Poland, these are the countries that after accession to the EU structures gained new possibilities for international activities, flows of capital, goods and services. Nevertheless, the dynamic of FDI within those countries was not homogenous (UNCTD, 2012). Poland, besides Hungary, is the leading country in respect of cumulative value of FDI located abroad among the "new members" of European Union (Ministry of Development, 2016). In the period of 2002-2005 Hungary demonstrated the highest level of FDI. After this Poland took the dominant position to gain a level of FDI (UNCTAD, 2015). The comparison is presented on Figure 4.

The increasing financial engagement of Polish companies made many of them transform into multinational corporations (MNC), with a strong position in the region or investing in the global dimension. In many cases, Polish companies internationalized through the traditional evolutionary model: expanding exports at the beginning and then investing in other projects supporting international sales and then developing production abroad. By collecting experience and knowledge about foreign markets during the process they are better prepared to increase their efficiency of the internationalization strategies and expansions into other markets. Nevertheless, in practice, many Polish companies omit intermediate steps and move straight to more advanced forms of internationalization, making them similar to many emerging markets' companies (Radło\&Ciesielska, 2016).

\footnotetext{
${ }^{4}$ Countries accessed EU in 2004: Poland, Slovakia, Cyprus, Slovenia, Hungary, Czech Republic, Estonia, Lithuania, Latvia, Malta; Countries accessed EU in 2007: Bulgaria, Romania; Croatia accessed EU in 2013
} 


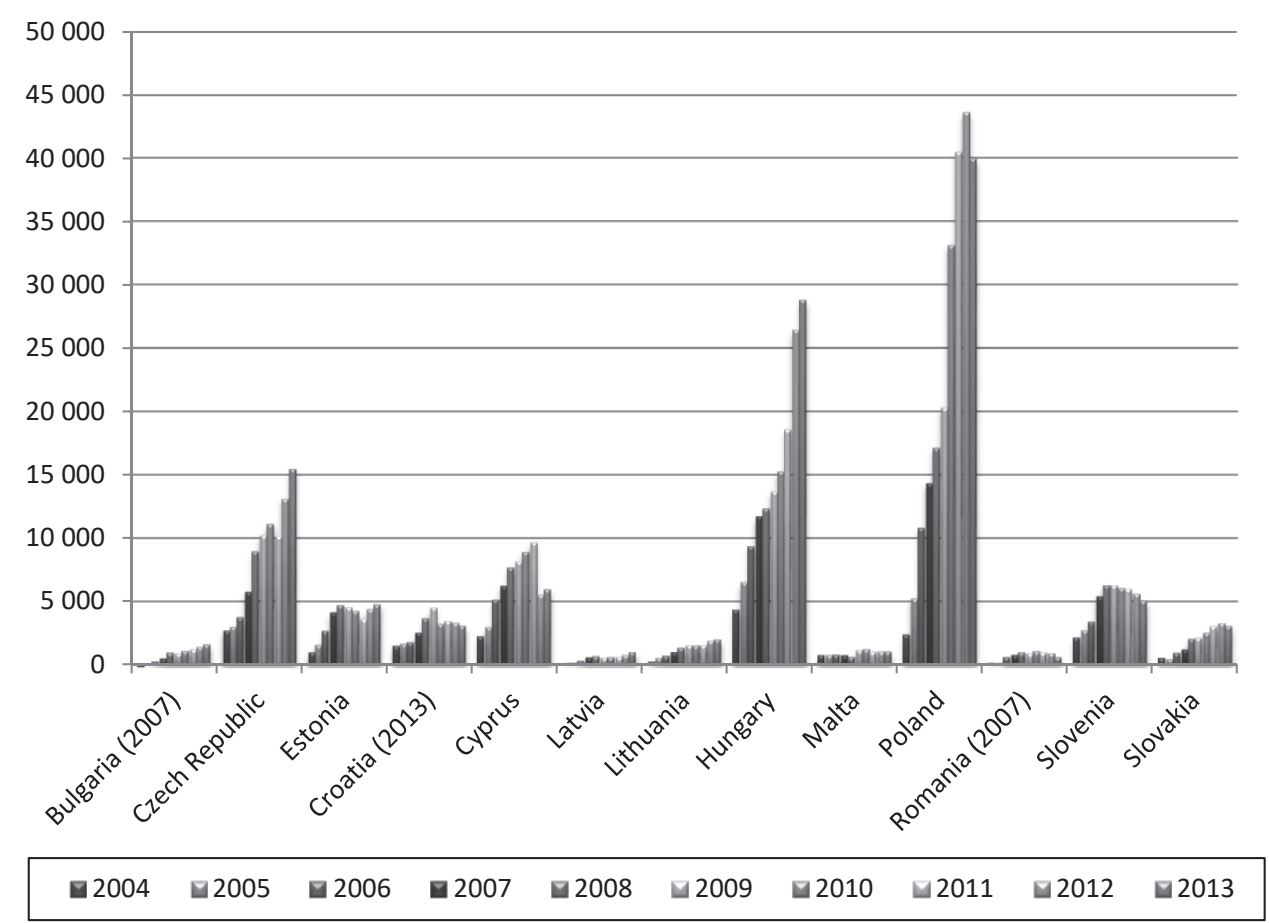

Figure 4. Total direct investment abroad (net position) of 13 „new” EU countries for 2004-2013 in $€ \mathrm{mln}$

Source: authors, based on: EUROSTAT

Table 2. Number of different FDI international projects of Polish companies for 2005-2014

\begin{tabular}{|c|c|c|c|c|}
\hline & $\begin{array}{c}\text { The number } \\
\text { of greenfield projects }\end{array}$ & $\begin{array}{c}\text { The value } \\
\text { of greenfield projects } \\
\text { in \$ } \mathbf{m}\end{array}$ & $\begin{array}{c}\text { The number of mergers } \\
\text { and acquisition projects }\end{array}$ & $\begin{array}{c}\text { The value of mergers } \\
\text { and acquisition projects } \\
\text { in \$ } \mathbf{~}\end{array}$ \\
\hline 2005 & 30 & 642 & 28 & 559 \\
\hline 2006 & 40 & 1,175 & 24 & 2,557 \\
\hline 2007 & 51 & 2,237 & 52 & 189 \\
\hline 2008 & 46 & 1,754 & 60 & 1,090 \\
\hline 2009 & 38 & 1,045 & 29 & 229 \\
\hline 2010 & 45 & 1,851 & 36 & 201 \\
\hline 2011 & 39 & 833 & 37 & 511 \\
\hline 2012 & 52 & 1,353 & 31 & 3,399 \\
\hline 2013 & 57 & 854 & 30 & 243 \\
\hline 2014 & 50 & 1,400 & 63 & 1,140 \\
\hline
\end{tabular}

Source: authors, based on Ministry of Development, 2016 
It is clear that Polish companies choose more advanced forms of expansion when investing on emerging markets, where they more often establish formal distribution partnerships or setting manufacturing agreements. Whereas it is more popular to start activities with export sales on the emerged markets (Radło\&Ciesielska, 2016). Among companies listed on the Warsaw Stock Exchange, the most popular strategy of entering foreign market was greenfield investment (83\%). Acquisition of overseas companies was chosen by $50 \%$ of listed companies. As a result, in the last decade, Polish companies made acquisitions of several hundred firms. Figure 5 and Table 3. show the share and the number of Polish companies with export sales in terms of the size of the enterprise.

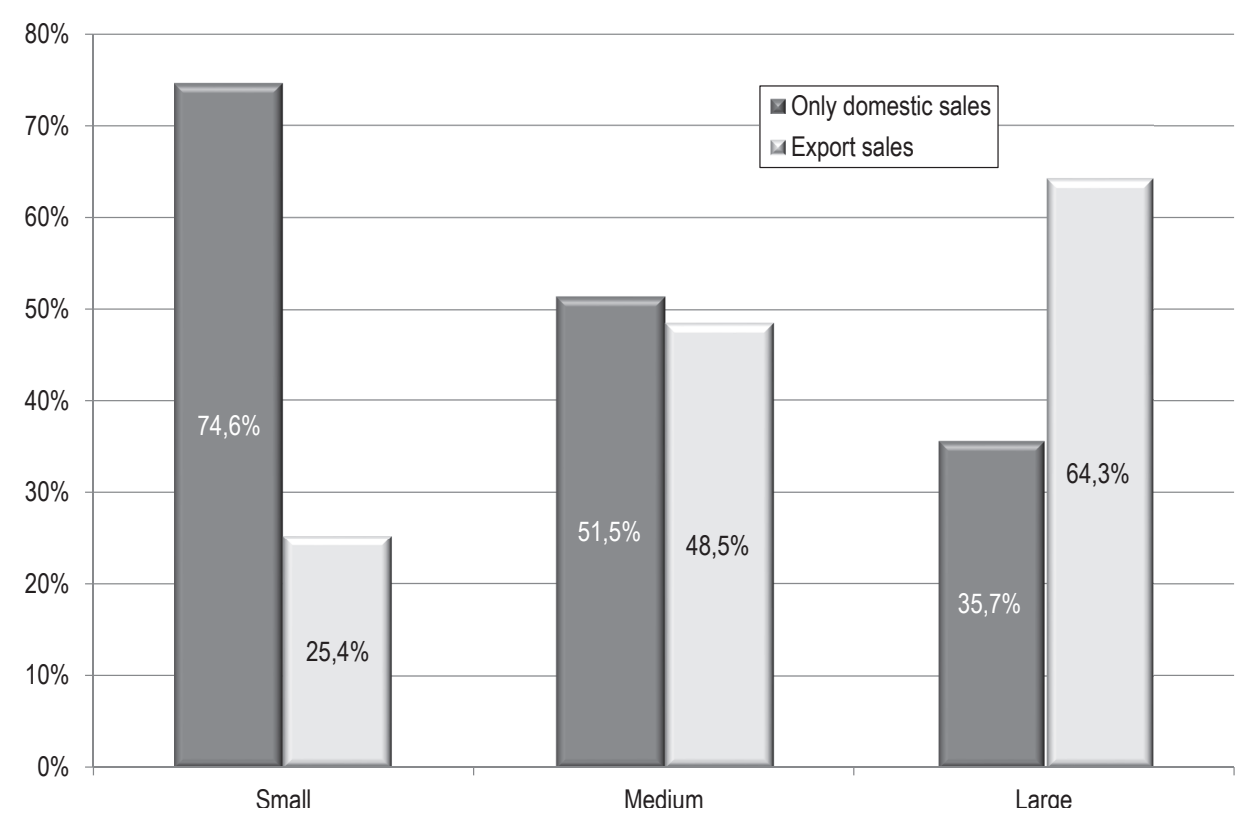

Figure 5. Polish Companies with Export Sales in 2015

Source: authors, based on: Financial results of economic entities in I-XII.2005Central Statistical Office, Warsaw 2016

Table 3. Polish Companies with Export Sales in 2015

\begin{tabular}{|l|r|r|r|r|r|r|}
\hline & \multicolumn{1}{|c|}{ Small } & \multicolumn{1}{c|}{ Small } & Medium & Medium & Large & Large \\
\hline Only domestic sales & 25149 & $74,6 \%$ & 7190 & $51,5 \%$ & 1159 & $35,7 \%$ \\
\hline Export sales & 8545 & $25,4 \%$ & 6758 & $48,5 \%$ & 2087 & $64,3 \%$ \\
\hline Total & 33694 & $100,0 \%$ & 13948 & $100,0 \%$ & 3246 & $100,0 \%$ \\
\hline
\end{tabular}

Source: authors, based on: Financial results of economic entities in I-XII.2005Central Statistical Office, Warsaw 2016 
Research on Polish enterprises shows that the experience gained even in a country with very similar business environment (e.g. Polish company investing in Czech, is then using this experience in entering Slovak market) cannot be treated as a factor of future success. Contrary, it shows that companies with lower experience, paradoxically are much more successful in dealing with a new business environment. This can come from the fact that they are more aware about the potential differences and putting more effort in preparing strategy of entering new market, including cultural differences (Barłożewski\&Trapczyński, 2016). Khanna (2015) underlines that it is more difficult to give up a working model and completely develop a whole new structure. This is especially true for enterprises that have already succeeded on foreign markets, have a welldeveloped operating model and possess a consistent business culture that worked in different local institutional contexts.

\section{Conclusions}

Almost $90 \%$ of Polish entrepreneurs still choose Western European countries as their direction of international expansion, this naturally results from the geographical and cultural proximity (Poland Go Global, 2016). Nevertheless high competition on European markets make them consider emerging markets as a future destination. Transition processes, formation of new institutional and economic reality, accompanied by painful reforms, followed by almost three decades of economic growth, can make Poland an interesting case to study in the context of the new global economy and the place of emerging and transition economies on its map. Activity on foreign markets is one of the determinants of economic development. As Khanna (2015) argues, adaptation to the cultural and institutional context has a greater impact on the future success on foreign markets than technological prowess or finance resources. It is therefore important to analyze the key determinants of success in entering new markets in the case of emerging and transition economies.

Analysis of data according to the international activities of Polish companies abroad combined with an analysis of the characteristics of Polish culture (based on two theoretical frameworks by G. Hofstede and R. Gesteland) provide the foundation for the main conclusions and thesis of this paper, which at the same time are the foundations for more in depth empirical studies and further areas of analysis. The key factors of successful entry strategies into new markets by Polish companies (in the context of socio-cultural and institutional aspects) can be summarised as follows:

1. Poland, as a Central European Country, places it in the middle of measures according to the some different criteria and determinants of cultural differences. As a representative of a medium individual culture Polish managers may be more predisposed to communicate and cooperate with both individual and collective cultures and be 
able to successfully adjust to the conditions in the new markets. It may be also a matter of characteristic tensions and contradictions within the Polish nation, that make people confident in dealing with high levels of diversity inside the home country.

2. Companies from markets in transition, facing lack of traditional advantages in comparison to developed economies' companies, can build competitive advantage by having specific knowledge about markets with similar institutional conditions to those that they were growing on. The difficult conditions of growing make them more resistant to a changing environment. At the same time they are more elastic and open to new strategies of expansion based on different forms of cooperation. These experiences yield a big advantage in comparison to their Western based competitors as well as emerging market rivals who are in the process of transformation. They are used to performing in less stable, dynamic and demanding institutional and administrative environment. Transformation can be a good lesson of necessity for adaptation.

3. Most of Polish companies' expansion strategies involve an approach based on establishing partnerships in new country or by acquisitions of local companies. The strategy based on the cooperation with good local partner plays significant role in entering new markets (Vide: Khanna, 2015) and, at the same time, minimizes the risk of failure. At the same time, Polish enterprises, especially small and medium, represent different organizational structures than most of the Western multinational companies, hence are less hampered by corporate rules and boundaries. What may be seen as an important advantage whit the reference to the international processes.

\section{References}

Barłożewski, K., Trapczyński, P. (2016). Ekspansja zagraniczna nie gwarantuje wzrostu. Harvard Business Review Polska, Feb 2016, 2 (156), (pp. 17-18).

Chhokar, J. S., Brodbeck, F. C., House, R. J. (2008). Culture and leadership across the world: the GLOBE book of in-depth studies of 25 societies. New York. NY. London, Psychology Press.

Ciesielska, D., Radło, M., (2015). Internationalization and Firm Performance of Companies Listed at the Warsaw Stock Exchange, Ekonomika i Organizacja Przedsiębiorstwa, 11/2015, pp. 92-102.

Ciesielska, D., Radło, M., J., Frasszczak, M., Spałek, P. (2016). Bezpośrednie inwestycje zagraniczne polskich przedsiębiorstw. Implikacje dla teorii i praktyki. Warszawa, Oficyna Wydawnicza SGH.

Dobbs, R., Koller, T., Ramaswamy, S. (2016). Przyszłość. Sposób na przetrwanie. Harvard Business Review Polska, Feb 2016, 2 (156), (pp. 94-107).

Dobbs, R. S., Koller, T., Manyika, J., Ramaswamy, Krishnan, R., \& Woetzel, J. (2016). Playing to Win: The New Global Competition for Corporate Profits. McKinsey Global Institute. 
Gesteland, R. R. (2005). Cross-cultural business behavior negotiating, selling, sourcing and managing across culture. Copenhagen, Copenhagen Business School Press 4th ed.

Hall, E. T., Hall, R. M., (1990). Understanding Cultural Differences. Germans, French and Americans. Yarmouth, Maine, Intercultural Press Inc.

House, R. J., Hanges, P. J., Javidan, M., Dorfman, P., Gupota, V. (2004). Culture, leadership, and organizations: the Globe study of 62 societies. Thousand Oaks. CA. London, SAGE.

House, R. J., Dorfman, P. W., Javidan, M., Hanges, P. J., Sully de Luque, M. F. (2014). Strategic leadership across cultures: the GLOBE study of CEO leadership behavior and effectiveness in 24 countries. Los Angeles, SAGE.

Hofstede G. H., Hofstede G. J. (2005). Cultures and organizations: software of the mind. New York. London, McGraw-Hill.

Hofstede, G. H., Hofstede, G. J., Minkov, M. (2010). Cultures and organizations: software of the mind: international cooperation and its importance for survival. New York. London, McGrawHill Rev. and expanded 3rd ed.

Hofstede G. (2001). Culture's consequences: comparing values, behaviors, institutions, and organizations across nations. Thousand Oaks. CA. London, SAGE.

Karaszewski, W., Jaworek, M., Kuzel, M., Szałucka, M., Szóstek, A., Kuczmarska, M. (2013). Aktywność inwestycyjna polskich przedsiębiorstw za granica - czynniki i skutki. Raport z badania. Toruń, Uniwersytet Mikołaja Kopernika w Toruniu.

Khanna, T., (2015). Inteligencja kontekstowa. Harward Business Review Polska, May 2015, 5 (147), (pp. 32-40).

Meyer, E. (2016). Gdy różnice kulturowe tworzą bariery. Harvard Business Review, April 2016, (158), (pp. 48-57).

Minkov, M., Hofstede, G. (2012). Hofstede's fifth dimension: new evidence from the world values survey. Journal of Cross-Cultural Psychology, January 2012, 43(1), p. 3(12).

Nakata, C. (2009). Beyond Hofstede. Culture Frameworks for Global Marketing and Management. Neeley, T., Kaplan, R. S. (2015). Określ strategię językową firmy. Harvard Business Review, May 2015, 5 (147), (pp. 44-53).

Rybinski, K., Wodecki, A., Smolinski, M., Kubisiak, P. (2016). Jak polskie firmy podbijają nowe rynki. Harvard Business Review Polska, May 2016, 159, (pp. 84-95).

Smolinski, M., Kubisiak, P. (2015). Sukces z etykietą „Made in Poland”. Harvard Business Review Polska, November 2015, 152 (pp. 10-15).

Stepien, B. (ed.) (2011). Międzynarodowa kooperacja gospodarcza z polskiej perspektywy. Warszawa, PWE.

Thomas, D. C., Peterson, M. F. (2015). Cross-Cultural Management. Essential Concept. Thousand Oaks. CA: SAGE.

Tietze S. (2008) (red.), International Management and Language, Routledge Studies in International Business and the World Economy. New York. Oxon, Routledge. 
Ministry of Development (2016). Polish Foreign Direct Investment in 2014. Ministry of Development, Development Strategy Department, Warszawa.

Polish Central Statistical Office (2012). Yearbook of Foreign Trade Statistics of Poland. Warsaw, Central Statistical Office. Retrieved from http://stat.gov.pl/ (access 03.12.2016).

Polish Central Statistical Office (2016a). Yearbook of Foreign Trade Statistics of Poland. Warsaw, Central Statistical Office.

Polish Central Statistical Office (2016b). Financial results of economic and entities in I-XII 2015. Warsaw, Central Statistical Office.

Polish Central Statistical Office (2016c). Activity of enterprises having foreign entities in the years 2008-2014. CSO. Warsaw, Central Statistical Office.

PwC (2012). Polski Czempion. Doświadczenia polskich firm inwestujących na rynkach zagranicznych. Report. Wrockaw. Warszawa, PwC.

United Nations Conference on Trade and Development (2012). World Investment Report. Towards a New Generation of Investment Polices. United Nations Conference on Trade and Development. New York and Geneva.

World Bank (2016). World Development Indicators 2016. Washington, DC, World Bank. Retrieved from https://openknowledge.worldbank.org/handle/10986/23969 (access 21.05.2018). http://www.polandgoglobal.pl/ (access 21.05.2018).

http://globeproject.com (access 21.05.2018).

http://www.worldvaluessurvey.org (access 21.05.2018).

http://www.businessnewsdaily.com/5241-international-marketing-fails.html (access 21.05.2018). http://data.worldbank.org/data-catalog/GDP-ranking-table (access 21.05.2018). 